\title{
Characterization of the Biodegradation of Kasbahs of the Gharb Region (Mehdia and Kenitra Kasbahs, Morocco)
}

\author{
Mohssine Zaidi ${ }^{1}$, Bouamar Baghdad ${ }^{2}$, Said Chakiri ${ }^{1}$, Abdelkader Taleb $^{2}$ \\ ${ }^{1}$ Faculty of Science, Department of Earth Science and the Universe, University of Ibn Tofail, Kenitra, Morocco \\ ${ }^{2}$ Department of Natural Resources and Environment, Institute of Agronomy and Veterinary Hassan II, Rabat, Morocco \\ Email:m.zaidi@mem.gov.ma
}

How to cite this paper: Zaidi, M., Baghdad, B., Chakiri, S. and Taleb, A. (2016) Characterization of the Biodegradation of Kasbahs of the Gharb Region (Mehdia and Kenitra Kasbahs, Morocco). Open Journal of Ecology, 6, 753-766.

http://dx.doi.org/10.4236/oje.2016.613067

Received: August 19, 2016

Accepted: December 18, 2016

Published: December 21, 2016

Copyright $\odot 2016$ by authors and Scientific Research Publishing Inc. This work is licensed under the Creative Commons Attribution International License (CC BY 4.0).

http://creativecommons.org/licenses/by/4.0/

\begin{abstract}
With the aim of contributing to the solutions linked to the problems of the preventive preservation and the restoration of the Kasbah of Mehdia or the Kasbah of Moulay El Hassan, a study of the flora populating the facades of these historical monuments was realized and showed the presence of a varied and diverse vegetation populating these buildings left to the ravages of time. The inventory of this flora showed the existence of 70 species among which 48 were exclusively detected at the Kasbah of Mehdia, 11 other species were only discovered at the Kasbah of Kenitra and 11 vegetal species were inventoried at both Kasbahs. These plant species are divided into 28 families. Four families clearly dominate the flora inventoried at both Kasbahs of the Gharb region. These are the Asteraceae (15.7\%), Poaceae (10\%), Apiaceae (8.6\%) and Scrophulariaceae (5.7\%). These families alone account for $41.4 \%$ of the specific size of the flora of the studied sites. The most dominant vegetal type is the therophytes with $61.4 \%$ of the total specific size, followed by hemicryptophytes with $17.1 \%$. Located at the top or the base of walls, these plants, fitting into joints or cracks, have a chemical action on the stones by acids which they release and also have a mechanical action on the stones by the growth of roots inside cracks. This vegetation remains one of the most important biological factors of the degradation of historical monuments.
\end{abstract}

\section{Keywords}

Weed Flora, Historical Monuments, Kasbahs, Kenitra, Mehdia, Morocco

\section{Introduction}

The stone of the buildings is constantly exposed to several deteriorating factors (wind, 
rain, sun, humidity, etc.). In addition, the effect of biodegradation allows organisms and different microorganisms to grow on any surface in the form of bio-films.

A careful examination at the Kasbah of Moulay El Hassan and the Kasbah of Mehdia shows that all the forms of the vegetal life can colonize the stones. We find indeed not only seaweeds, mushrooms, lichens, but also froths (mosses), ferns and vascular plants there. Because these buildings are poorly maintained, it is not rare to find trees of which roots are obviously devastating.

The Kasbah of Kenitra was built by Sultan Moulay El Hassan and was completed by his successor Moulay Abdelaziz in 1895 [1]. It is about a citadel at the heart of the city of Kenitra, which is, at present, considered as one of the most modern Moroccan big cities and one of the most important cities of the northwest of the Kingdom (Figure 1). It is a recent city, contrary to the imperial cities of the Kingdom, because its creation goes back to only 120 years.

Mehdia's Kasbah was built in the sixth century before J.C. by the Suffete Hannon, the first magistrate of Carthage, and was restored for the first time in 1185 by Sultan Yacoub El Mansour [2]. It is located at the level of the Mehdia's picturesque coastal town situated on the west of the city of Kenitra at a distance of approximately $10 \mathrm{~km}$.

The city of Kenitra is located in the north-west of Morocco, near the Atlantic Ocean between Rabat and Tangier. It is built on the bank of the Oued Sebou and located 40 $\mathrm{km}$ in the north of the capital Rabat with latitude: $34^{\circ} 08^{\prime} 00^{\prime \prime}$ North and longitude: $6^{\circ} 34^{\prime} 00^{\prime \prime}$ West.

The city of Mehdia is located in the west of the city of Kenitra at a distance of about

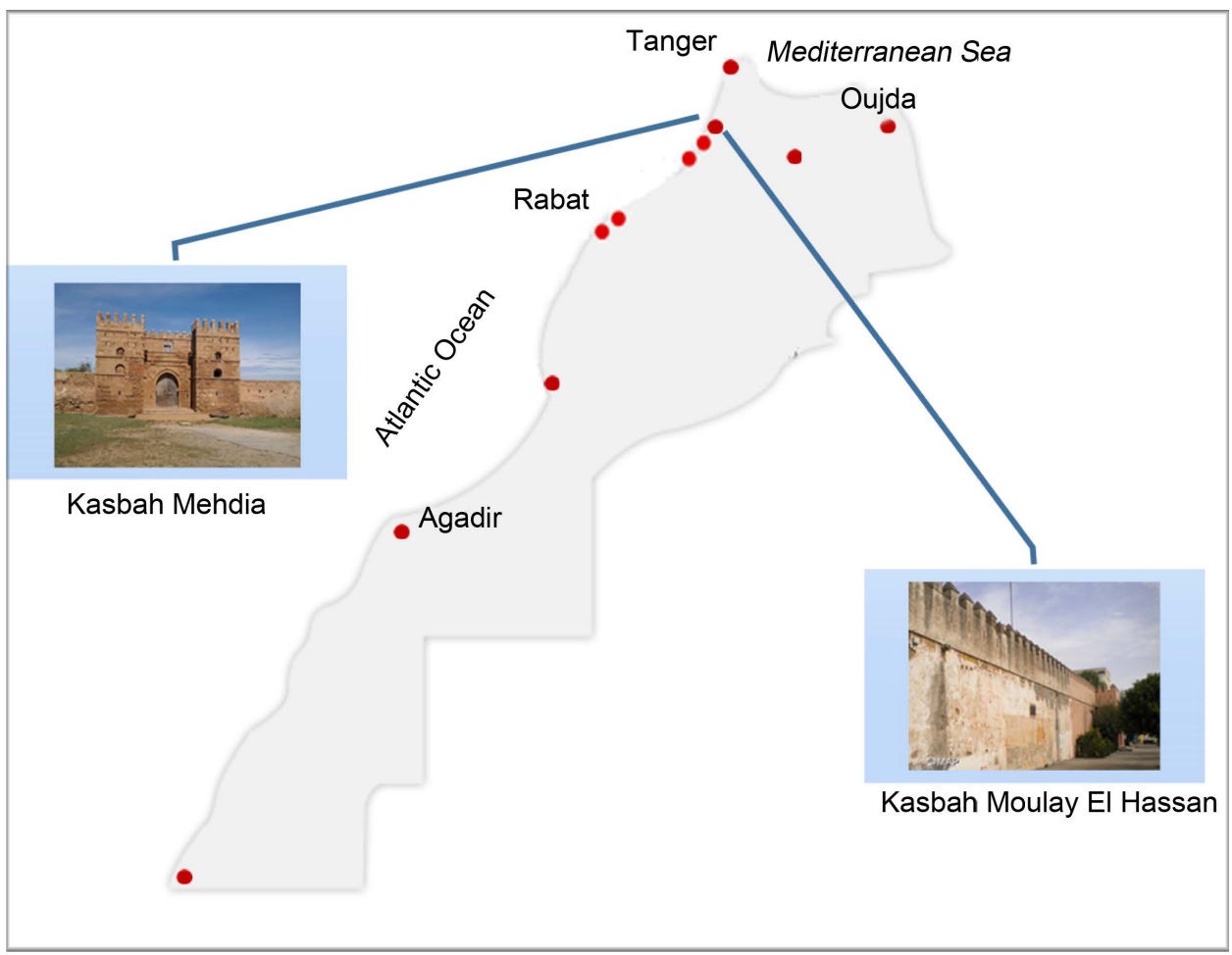

Figure 1. Location of Moulay El Hassan and Mehdia Kasbah's. 
$10 \mathrm{~km}$. It is bounded by the Atlantic Ocean to the west, Sebou River and Lake Sidi Boughaba to the north and the rural commune of Sidi Taibi to the south.

The cities of Kenitra and Mehdia are situated in the center of a rich agricultural region, Gharb. Besides the sea of Mehdia beach, we find near these cities, the biological reserve of the lake Sidi Boughaba, classified site RAMSAR, and its numerous species of migratory birds, as well as the forest of the cork oak of Maamoura.

The climate at the level of the cities of Kenitra and Mehdia is hot and moderate. The winter characterized by precipitation is more important than in summer. The annual average temperature is of $18.4^{\circ} \mathrm{C}$ there. The average of the annual precipitation reaches $570 \mathrm{~mm}$.

The objective of this study is to inventory and characterize the flora inhabiting the construction of two Kasbah of the Gharb region. This inventory will doubtless help other specialists to make concrete proposals of conservation and the restoration and the rehabilitation of these monuments.

\section{Material and Methods}

\subsection{Sampling}

The floristic surveys were realized according to a systematic sampling in the facades of the most important walls of the Kasbah of Kenitra and the Kasbah of Mehdia. Facades chosen in this study are the most affected by macro and microorganisms (Figure 2 and
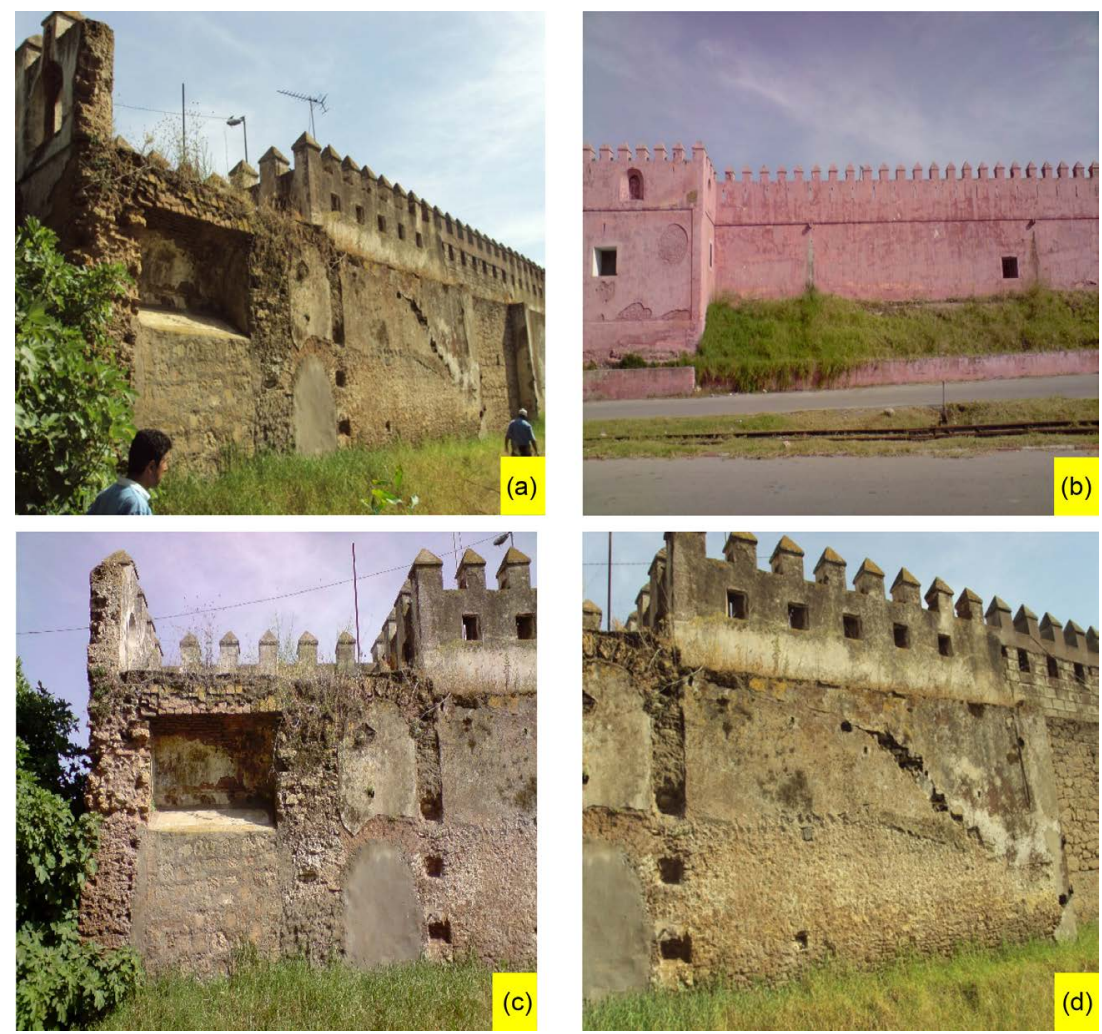

Figure 2. Facades of some walls considered in the floristic inventory at the Kasbahof Moulay El Hassan in Kenitra ((a), (b), (c) and (d)). 
Figure 3). The method adopted during these surveys consists in inventorying the various types of existing flora on each facade of the wall studied according to three separate places: basal Part, middle part and the top of the wall. So, a herbarium was established at each Kasbah.

The study of the flora populating building materials in the Kasbah of Kenitra and that of Mehdia revealed diversified vegetation. Left with the ravage of time without any restoration and rehabilitation, both studied Kasbahs contain several facades invaded by various types of vegetation.

The floristic surveys at both Kasbahs were realized during the period between the months of March and April 2014.

\subsection{Species Identification}

The determination of the plant species, taken at the Kasbah of Moulay El Hassan and Mehdia one, was made in the Department of Natural Resources and Environment, of Vegetable Ecology, at the Agronomic and Veterinary Institute Hassan II in Rabat thanks to the following florae: the flora illustrated with adventitious of the cultures of Gharb [3], the flora has a practice of Morocco [4] [5] [6]. The check of the identifications was made by referring to the Catalog of the Plants of Morocco [7] and the synonymic Index of let us tax presents in the cultivated circles and artificializes of Morocco. The nomenclature used is the flora of Morocco [4] [5] [6].
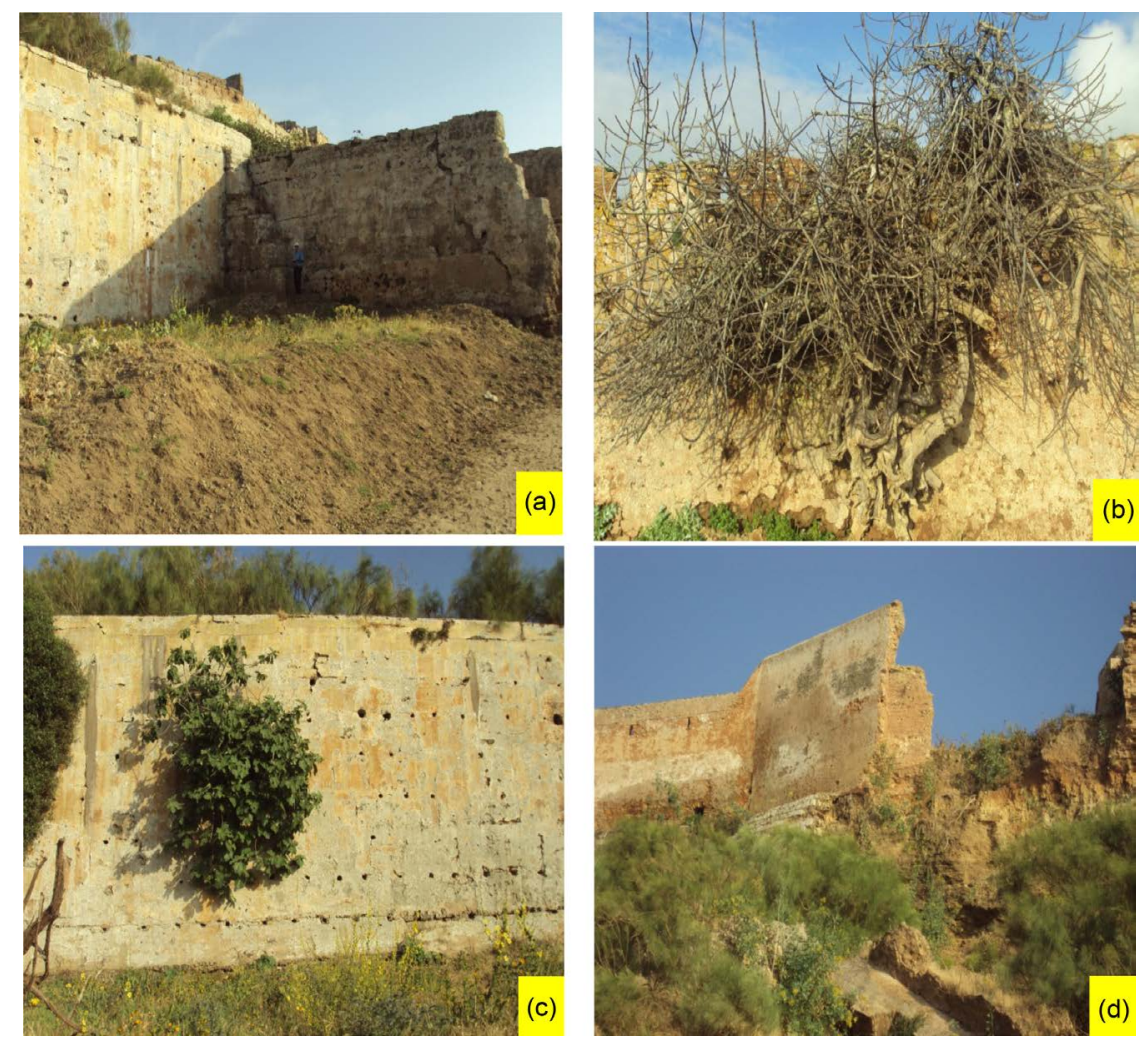

Figure 3. Internal and external facades of some walls considered in the floristic inventory at the Kasbah of Mehdia ((a), (b), (c) and (d)). 


\section{Results}

\subsection{The Kasbah of Mehdia}

\section{- Systematic appearance}

Table 1 presents an exhaustive list of the vegetal species found at facades of the walls studied at the Kasbah of Mehdia. These inventoried species are in number of fifty nine (59), distributed on fifty four (54) genus and twenty six (26) vegetal families.

According to their relative contributions, four families dominate clearly the flora populating the historical buildings of the Kasbah of Mehdia, namely:

$\checkmark$ Astereaceae (15.2\%) with 09 species;

$\checkmark$ Poaceae (10.1\%) with 06 species;

$\checkmark$ Apiaceae (8.5\%) with 05 species;

$\checkmark$ Scrophulariaceae (6.7\%) with 04 species.

These families totaled 24 species alone, or $40.6 \%$ of the specific size of the flora of the site.

The importance of these families can be explained by their preponderances nationally, their Mediterranean biogeographical distribution and their ability to adapt to unstable and highly diverse habitats [8] and more of high productivity seeds, the to revise longevity of seeds, seed dispersal by wind and birds and phenology perfectly suited to the nature of building materials of historical monuments [9].

\section{- Biological aspect}

To decide the form ethology, the classification adopted as ethology notation reference observed and dominant in the field is that of Raunkiaer [10], which is based on the position of permanent buds during the period of vegetative rest with respect to the surface soil.

The spectrum established for the entire weed flora, detected in the walls of the Kasbah of Mehdia, reveals five biological types (Table 2). This flora is dominated by therophytes (annual) comprise 38 species or $64.4 \%$ of the specific effective, followed by hemicryptophytes with 8 species or $13.5 \%$ of the specific effective and phanerophytes with $10.2 \%$ the actual inventory to the site (Table 2).

\subsection{The Kasbah of Kenitra}

\section{- Systematic Appearance}

Table 3 shows the plant species encountered in the various fronts of walls studied at the Kasbah of Moulay El Hassan. These species are inventoried number of twenty-two (22) spread over thirteen (13) botanical families.

According to their relative contributions, two (02) families dominate sharply flora inhabiting the historic walls of the Kasbah of Moulay El Hassan in genera and species, namely:

$\checkmark$ Astereaceae (18.18\%) with 04 species;

$\checkmark$ Poaceae (18.18\%) with 04 species.

These two families totaling 08 species alone, or $36.36 \%$ of the specific size of the flora of the site. 
Table 1. Vegetal species found in the historical buildings of the Kasbah of Mehdia divided into vegetal families.

\begin{tabular}{|c|c|c|c|}
\hline Families & Species & Number of species & Biological type \\
\hline \multirow{5}{*}{ Apiaceae } & Ammimajus & \multirow{5}{*}{5} & Therophyte \\
\hline & Ammivisnaga & & Therophyte \\
\hline & Smyrniumolusatrum & & Hemicryptophyte \\
\hline & Torilisarvensis & & Therophyte \\
\hline & Torilisnodosa & & Therophyte \\
\hline \multirow[t]{5}{*}{ Araceae } & Arisarum vulgare & \multirow[t]{2}{*}{1} & Geophyte \\
\hline & Carduusmyriacanthus & & Therophyte \\
\hline & Chrysanthemum coronarium & \multirow{8}{*}{9} & Therophyte \\
\hline & Hypochoerisradicata & & Hemicryptophyte \\
\hline & Phagnalon saxatile & & Phanerophyte \\
\hline \multirow[t]{5}{*}{ Asteraceae } & Scolymus maculatus & & Therophyte \\
\hline & Sonchus oleraceus & & Therophyte \\
\hline & Taraxacumofficinale & & Therophyte \\
\hline & Urospermumpicroides & & Therophyte \\
\hline & Reichardia tingitana & & Therophyte \\
\hline \multirow{2}{*}{ Brassicaceae } & Diplotaxis catholica & \multirow{2}{*}{2} & Therophyte \\
\hline & Lobularia lybica & & Therophyte \\
\hline Caryophyllaceae & Cerastium glomeratum & 1 & Therophyte \\
\hline \multirow{2}{*}{ Chenopodiaceae } & Beta maritima & \multirow{2}{*}{2} & Hemicryptophyte \\
\hline & Chenopodium murale & & Therophyte \\
\hline Convolvulaceae & Convolvulus althaeoides & 1 & Geophyte \\
\hline \multirow[t]{2}{*}{ Crassulaceae } & Cotyledon umbilicus-veneris & \multirow[t]{2}{*}{1} & Therophyte \\
\hline & Euphorbia helioscopia & & Therophyte \\
\hline \multirow[t]{2}{*}{ Euphorbiaceae } & Mercurialis annua & \multirow[t]{2}{*}{3} & Therophyte \\
\hline & Ricinus communis & & Phanerophyte \\
\hline \multirow{2}{*}{ Fabaceae } & Lotus arenarius & \multirow[t]{2}{*}{2} & Therophyte \\
\hline & Retama monosperma & & Phanerophyte \\
\hline \multirow{2}{*}{ Geraniaceae } & Geranium molle & \multirow{2}{*}{2} & Therophyte \\
\hline & Geranium sp. & & Therophyte \\
\hline \multirow{3}{*}{ Lamiaceae } & Ajuga iva & \multirow{3}{*}{3} & Hemicryptophyte \\
\hline & Marrubium vulgare & & Chamaeophyte \\
\hline & Stachys ocymastrum & & Therophyte \\
\hline \multirow{2}{*}{ Malvaceae } & Malva hispanica & \multirow{2}{*}{2} & Therophyte \\
\hline & Malva parviflora & & Therophyte \\
\hline Moraceae & Ficus carica & 1 & Phanerophyte \\
\hline Myoporaceae & Myoporum sp. & 1 & Phanerophyte \\
\hline Papaveraceae & Papaver rhoeas & 1 & Therophyte \\
\hline Plantaginaceae & Plantago lanceolata & 1 & Hemicryptophyte \\
\hline Plumbaginaceae & Plumbago europaea & 1 & Hemicryptophyte \\
\hline \multirow{6}{*}{ Poaceae } & Brachypodium distachyum & \multirow{6}{*}{6} & Therophyte \\
\hline & Bromus rigidus & & Therophyte \\
\hline & Cynodon dactylon & & Geophyte \\
\hline & Hordeummurinum & & Therophyte \\
\hline & Lagurusovatus & & Therophyte \\
\hline & Loliumrigidum & & Therophyte \\
\hline Polygonaceae & Emex spinosa & 1 & Therophyte \\
\hline
\end{tabular}




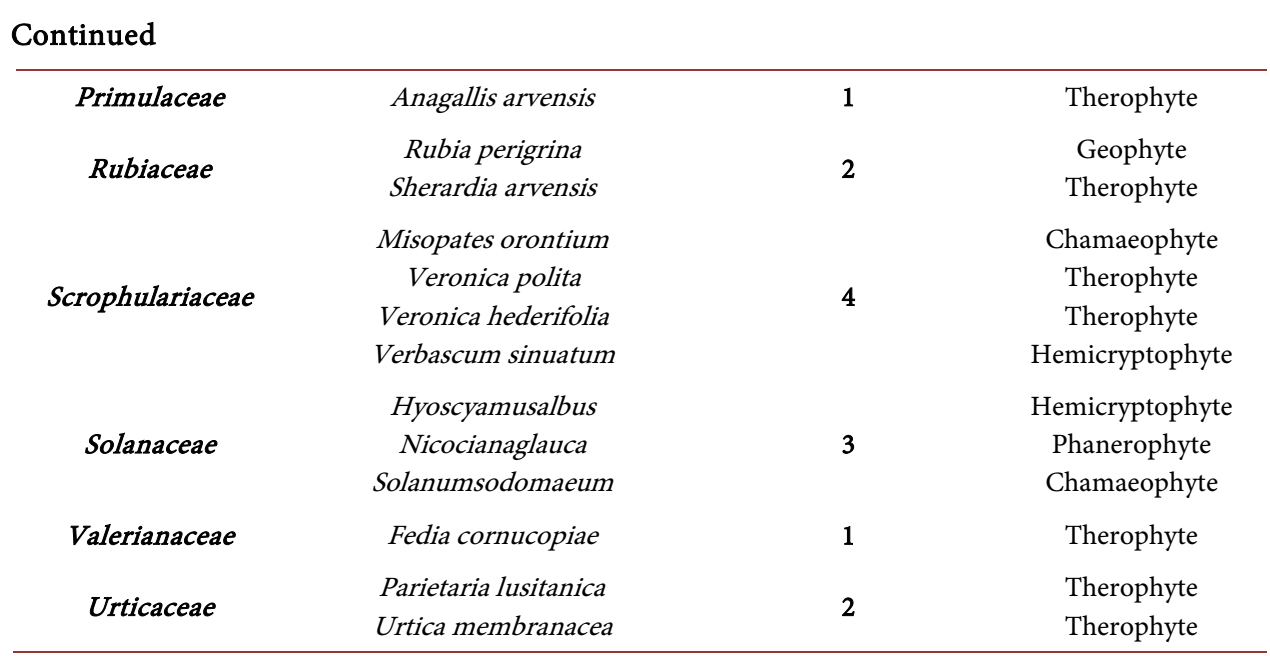

Table 2. Biological spectrum at the Kasbah of Mehdia.

\begin{tabular}{ccc}
\hline Biological type & Number of species & Contributions (\%) \\
\hline Therophyte & 38 & 66.1 \\
Hemicryptophytes & 8 & 11.9 \\
Phanerophytes & 6 & 10.2 \\
Geophytes & 4 & 6.8 \\
Chamaeophytes & 3 & 5 \\
Total & 59 & 100 \\
\hline
\end{tabular}

\section{- Biological Appearance}

According to the classification of Raunkiaer [10], the 22 weed species belong to four biological types. This flora is clearly dominated by therophytes (annual) comprise 13 species or $59.1 \%$ of the specific effective, followed by hemicryptophytes with 5 species or $22.7 \%$, geophytes with $3 \%$ cash soit 13.6 and phanerophytes with one species or $4.6 \%$ of the specific strength (Table 4).

\subsection{Comparison between the Two Kasbahs}

From Table 1 and Table 3, we can deduct that the total number of the botanical species inventoried at the two studied Kasbahs in the Gharb region sum-up to 70 species among which 48 are exclusively detected in the Kasbah of Mehdia, 11 other species are only discovered in the Kasbah of Kenitra and 11 vegetal species are simultaneously inventoried at both Kasbahs (Table 5).

The abundance of plant flora at the Kasbah of Mehdia, compared to that of Kenitra, is due to the large area of the monument (40 hectares) on the one hand, and the lack of recovery operations and systematic rehabilitation at the second Kasbah. Thus, the walls of several monumental buildings of this building are colonized by a variety of vegetation that certainly have a detrimental effect on the stones used in the construction of this historic site (Figure 3). At the level of the Kasbah of Kenitra, the invasion of the facades of the walls by the flora is less important compared to the Kasbah of Mehdia. 
Table 3. Plant species encountered in the studied walls of the Kasbah of Moulay El Hassan in Kenitra divided into botanical families.

\begin{tabular}{|c|c|c|c|}
\hline Families & Species & Number of species & Biological type \\
\hline Amaranthaceae & Amaranthusviridis & 1 & Therophyte \\
\hline Apiaceae & Conium maculatum & 1 & Hemicryptophyte \\
\hline \multirow{4}{*}{ Asteraceae } & Scolymusmaculatus & \multirow{4}{*}{4} & Therophyte \\
\hline & Sonchusoleraceus & & Therophyte \\
\hline & Andryalaintegrifolia & & Therophyte \\
\hline & Erigeron canadensis & & Geophyte \\
\hline Boraginaceae & Heliotropiumeuropaeum & 1 & Therophyte \\
\hline \multirow{2}{*}{ Caryophyllaceae } & Silene vulgaris & \multirow{2}{*}{2} & Geophyte \\
\hline & Polycarpontetraphyllum & & Therophyte \\
\hline Chenopodiaceae & Chenopodiumambrosoides & 1 & Hemicryptophyte \\
\hline \multirow{2}{*}{ Euphorbiaceae } & Mercurialisannua & \multirow{2}{*}{2} & Therophyte \\
\hline & Ricinus communis & & Phanerophyte \\
\hline \multirow{3}{*}{ Plantaginaceae } & Plantagolanceolata & \multirow{2}{*}{2} & Hemicryptophyte \\
\hline & Plantagomajor & & Hemicryptophyte \\
\hline & Oryzopsismiliacea & \multirow{4}{*}{4} & Hemicryptophyte \\
\hline \multirow{3}{*}{ Poaceae } & Cynodondactylon & & Geophyte \\
\hline & Lagurusovatus & & Therophyte \\
\hline & Bromusrigidus & & Therophyte \\
\hline Primulaceae & Anagallisarvensis & 1 & Therophyte \\
\hline Rubiaceae & Galiumaparine & 1 & Therophyte \\
\hline Scrophulariaceae & Verbascumsinuatum & 1 & Hemicryptophyte \\
\hline Urticaceae & Parietarialusitanica & 1 & Therophyte \\
\hline
\end{tabular}

Table 4. Spectrum ethology at the kasbah of Kenitra.

\begin{tabular}{ccc}
\hline Ethological type & Number of species & Contributions (\%) \\
\hline Therophytes & 12 & 54.6 \\
Hemicryptophytes & 6 & 27.3 \\
Geophytes & 3 & 13.6 \\
Phanerophytes & 1 & 4.5 \\
Total & 22 & 100 \\
\hline
\end{tabular}

This is due to maintenance has suffered this monument over time, although they are inadequate and are, themselves, a factor of degrading this Kasbah. However, the review of internal facades of the walls, left without maintenance, surrounding the Kasbah, also showed a marked diversification of vegetation inhabiting this building (Figure 2).

The total number of these plant species is divided into 28 botanical families. According to their relative contributions, four (4) families clearly dominate the flora inventoried at both Kasbahs of the region of Gharb. There are: 
Table 5. Plant species encountered at both Kasbah of Kenitra and Mehdia divided into botanical families.

\begin{tabular}{|c|c|c|c|c|}
\hline Families & Species & Location & Number of species & s Biological type \\
\hline \multirow[t]{3}{*}{ Amaranthaceae } & Amaranthusviridis & K.Kenitra & 1 & Therophyte \\
\hline & Ammimajus & K. Mehdia & & Therophyte \\
\hline & Ammivisnaga & K. Mehdia & & Therophyte \\
\hline \multirow{4}{*}{ Apiaceae } & Smyrniumolusatrum & K. Mehdia & & Hemicryptophyte \\
\hline & Torilisarvensis & K. Mehdia & 6 & Therophyte \\
\hline & Torilisnodosa & K. Mehdia & & Therophyte \\
\hline & Conium maculatum & K. Kenitra & & Hemicryptophyte \\
\hline \multirow[t]{6}{*}{ Araceae } & Arisarum vulgare & K. Mehdia & 1 & Geophyte \\
\hline & Carduusmyriacanthus & K. Mehdia & & Therophyte \\
\hline & Chrysanthemum coronarium & K. Mehdia & & Therophyte \\
\hline & Hypochoerisradicata & K. Mehdia & & Hemicryptophyte \\
\hline & Phagnalon saxatile & K. Mehdia & & Phanerophyte \\
\hline & Scolymus maculatus & K. Mehdia + K. Kenitra & & Therophyte \\
\hline \multirow[t]{6}{*}{ Asteraceae } & Sonchus oleraceus & K. Mehdia + K. Kenitra & 11 & Therophyte \\
\hline & Taraxacumofficinale & K. Mehdia & & Therophyte \\
\hline & Urospermumpicroides & K. Mehdia & & Therophyte \\
\hline & Reichardia tingitana & K. Mehdia & & Therophyte \\
\hline & Andryalaintegrifolia & K. Kenitra & & Therophyte \\
\hline & Erigeron canadensis & K. Kenitra & & Geophyte \\
\hline Boraginaceae & Heliotropiumeuropaeum & K. Kenitra & 1 & Therophyte \\
\hline \multirow{3}{*}{ Brassicaceae } & Diplotaxis catholica & K. Mehdia & & Therophyte \\
\hline & Lobularia lybica & K. Mehdia & 2 & Therophyte \\
\hline & Cerastium glomeratum & K. Mehdia & & Therophyte \\
\hline \multirow[t]{3}{*}{ Caryophyllaceae } & Silene vulgaris & K. Kenitra & 3 & Geophyte \\
\hline & Polycarpontetraphyllum & K. Kenitra & & Therophyte \\
\hline & Beta maritima & K. Mehdia & & Hemicryptophyte \\
\hline \multirow[t]{2}{*}{ Chenopodiaceae } & Chenopodium murale & K. Mehdia & 3 & Therophyte \\
\hline & Chenopodiumambrosoides & K. Kenitra & & Hemicryptophyte \\
\hline Convolvulaceae & Convolvulus althaeoides & K. Mehdia & 1 & Geophyte \\
\hline \multirow[t]{2}{*}{ Crassulaceae } & Cotyledon umbilicus-veneris & K.Mehdia & 1 & Therophyte \\
\hline & Euphorbia heliscopia & K.Mehdia & & Therophyte \\
\hline \multirow[t]{2}{*}{ Euphorbiaceae } & Mercurialis annua & K. Mehdia + K. Kenitra & 3 & Therophyte \\
\hline & Ricinus communis & K. Mehdia + K. Kenitra & & Phanerophyte \\
\hline \multirow{2}{*}{ Fabaceae } & Lotus arenarius & K. Mehdia & 2 & Therophyte \\
\hline & Retama monosperma & K. Mehdia & & Phanerophyte \\
\hline \multirow{2}{*}{ Geraniaceae } & Geranium molle & K. Mehdia & 2 & Therophyte \\
\hline & Geranium sp. & K. Mehdia & 2 & Therophyte \\
\hline \multirow{3}{*}{ Lamiaceae } & Ajuga iva & K. Mehdia & & Hemicryptophyte \\
\hline & Marrubium vulgare & K. Mehdia & 3 & Chamaeophyte \\
\hline & Stachys ocymastrum & K. Mehdia & & Therophyte \\
\hline \multirow{2}{*}{ Malvaceae } & Malva hispanica & K. Mehdia & \multirow{2}{*}{2} & Therophyte \\
\hline & Malva parviflora & K. Mehdia & & Therophyte \\
\hline Moraceae & Ficus carica & K. Mehdia & 1 & Phanerophyte \\
\hline Myoporaceae & Myoporum sp. & K. Mehdia & 1 & Phanerophyte \\
\hline Papaveraceae & Papaver rhoeas & K. Mehdia & 1 & Therophyte \\
\hline \multirow{2}{*}{ Plantaginaceae } & Plantago lanceolata & K. Mehdia + K. Kenitra & 2 & Hemicryptophyte \\
\hline & Plantago major & K. Kenitra & 2 & Hemicryptophyte \\
\hline
\end{tabular}




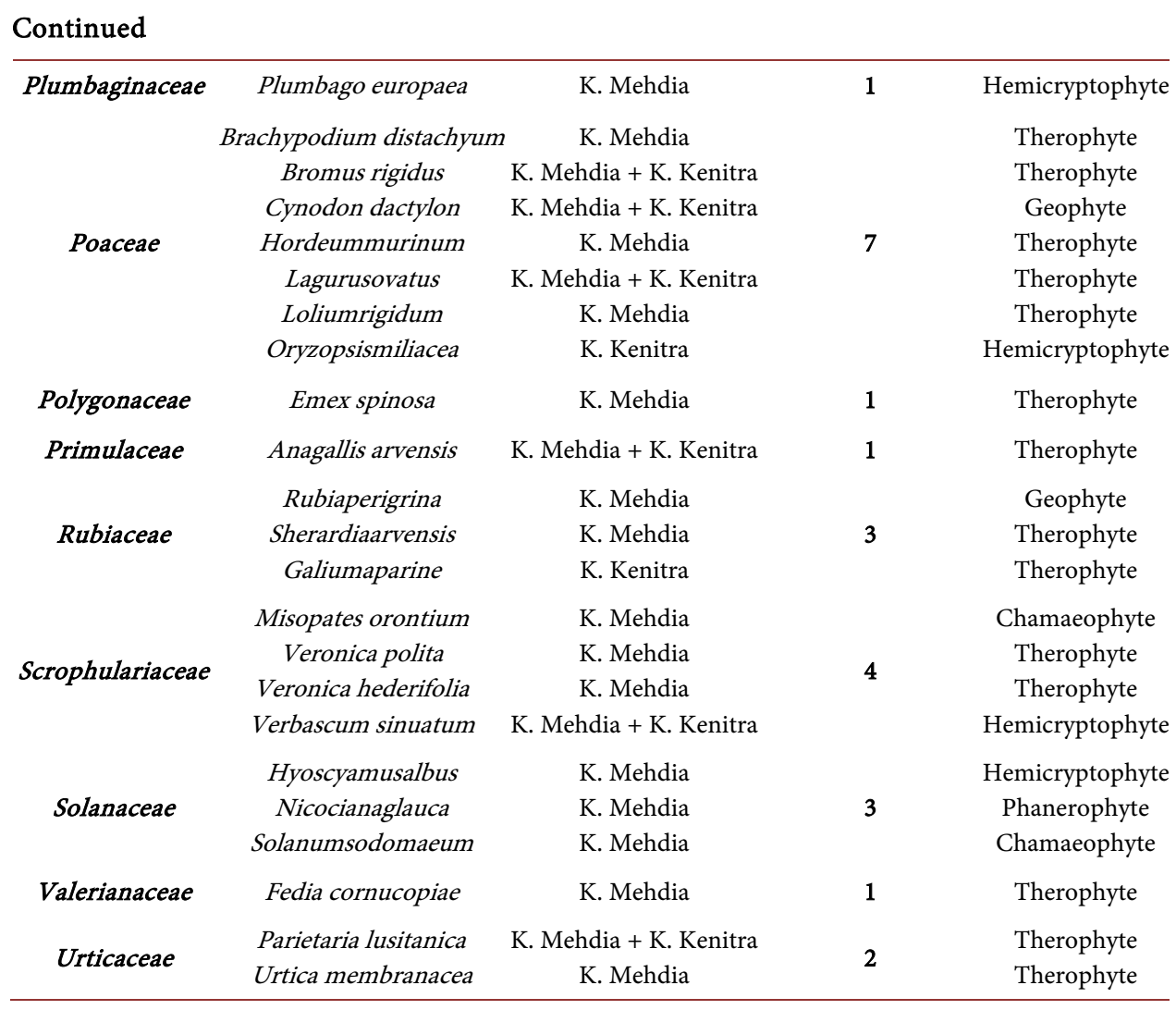

$\checkmark$ Astereaceae (15.7\%) with 11 species;

$\checkmark$ Poaceae (10\%) with 07 species;

$\checkmark$ Apiaceae (8.6\%) with 06 species;

$\checkmark$ Scrophulariaceae (5.7\%) with 04 species.

These families alone totaled $41.4 \%$ of the specific size of the flora of the sites.

The spectrum established for the entire weed flora, detected in the walls of the Kasbah and the Kenitra Mehdia, reveals five biological types. This flora is dominated by therophytes, which consist of 43 species or $61.4 \%$ of the specific effective, followed by hemicryptophytes with 12 species or $17.1 \%$ of the specific strength (Table 6).

\section{Action of Plants, Algae and Lichen on Monuments}

Many living organisms can easily colonize stonework and be responsible, in addition to their unattractive character, more or less significant damage [11]. Biological weathering agents are mainly mosses, fungi and lichens, algae but also some bacteria and some plants.

Plants growing on buildings generally indicate the presence of moisture in the attached materials. After sowing (presence of seeds), the environmental parameters which promote the growth of these plants are light, oxygen and carbon dioxide. Inorganic salts derived from stone materials [12]. In general, the roots accentuate the deterioration of masonry. The presence of plants on buildings mainly reflects a lack of maintenance of the building [12] (Figure 4). 
These herbs, vines and shrubs that thrive are destructive buildings because their root systems seep into cracks and joints between stone exerting enough pressure to significant fragmentation of the stone (Figure 5). They also generate moist micro-soils, which are a source of salt and place of intense biological activity [13].

Table 6. Ethology spectrum at the Kasbah of Kenitra and Mehdia.

\begin{tabular}{ccc}
\hline Ethological type & Number of species & Contributions in \% \\
\hline Therophytes & 43 & 61.4 \\
Hmicryptophytes & 12 & 17.1 \\
Phanerophytes & 6 & 8.6 \\
Geophytes & 6 & 8.6 \\
Chamaeophytes & 3 & 4.3 \\
Total & 70 & 100 \\
\hline
\end{tabular}

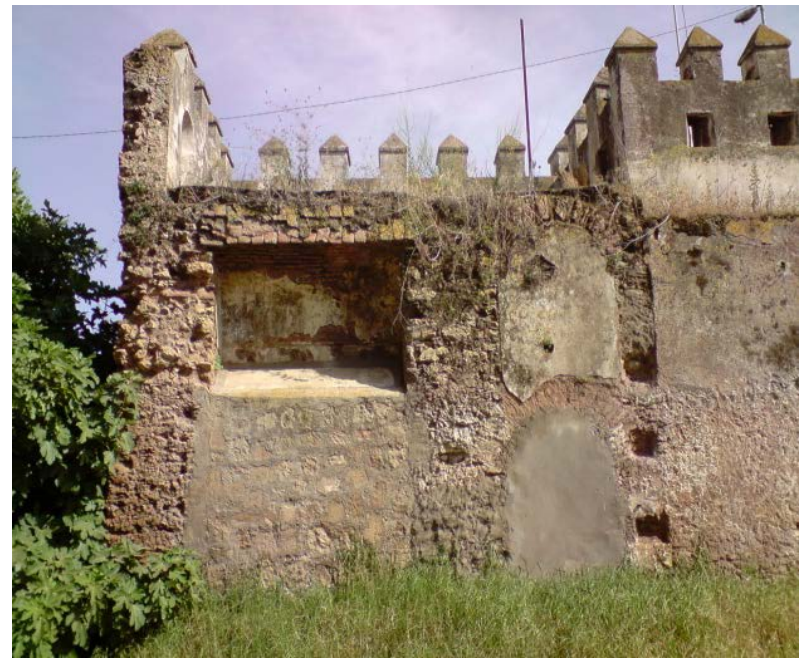

Figure 4. Colonization facades of walls by higher plants at the Kasbah of Kenitra.
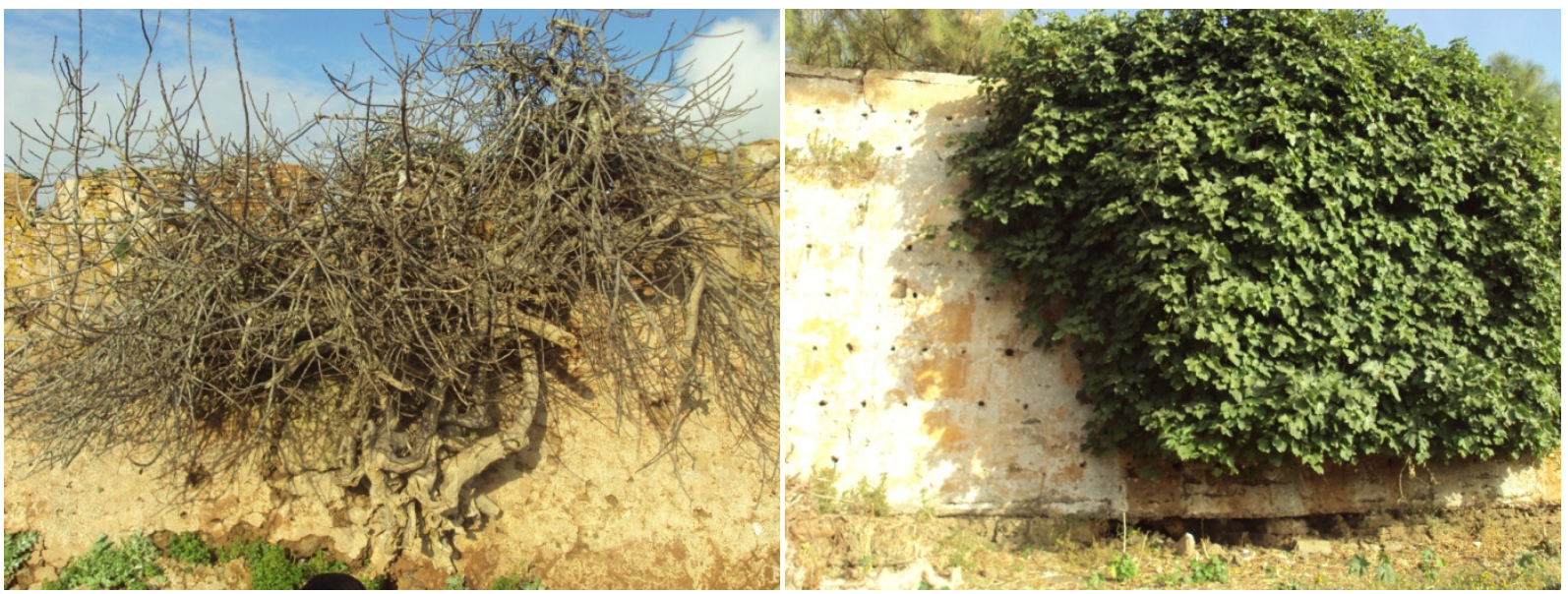

Figure 5. Development of herbs and shrubs joints between the stones at the walls at the Kasbah of Mehdia. 
On the other hand, the presence of mosses and plants at the historical monuments, including the facades of the walls of the Kasbah of Kenitra (Figure 6(a)) and the Kasbah of Mehdia (Figure 6(b)), already indicates a certain degree alteration which must be fixed.

The development of fungi and lichens can be destructive [14] because it weakens the stone locally mechanically by the growth of their fronds embedded in the stone and their roots, rhizines. These roots can penetrate deep into the stone in chemical form; because the stone is attacked by the release of their metabolisms such as oxalic acid that attacks the carbonates to form oxalates often responsible for ocher color of the stone surface [15]. Foams are less harmful than lichens but they maintain moisture on the walls, which promotes the growth of bacteria. They are often found at the base of the walls, where occur rising damp from the ground [16] (Figure 7).

\section{Conclusions}

The study of the flora of the Kasbah of Kenitra and Mehdia was especially centered on the superior vegetables populating the facades of the studied walls. The inventory of this flora showed the existence of much-diversified vegetation. By its chemical action and its mechanical effect on stones of the buildings, this flora deeply contributes to the degradation of the studied historical monuments.
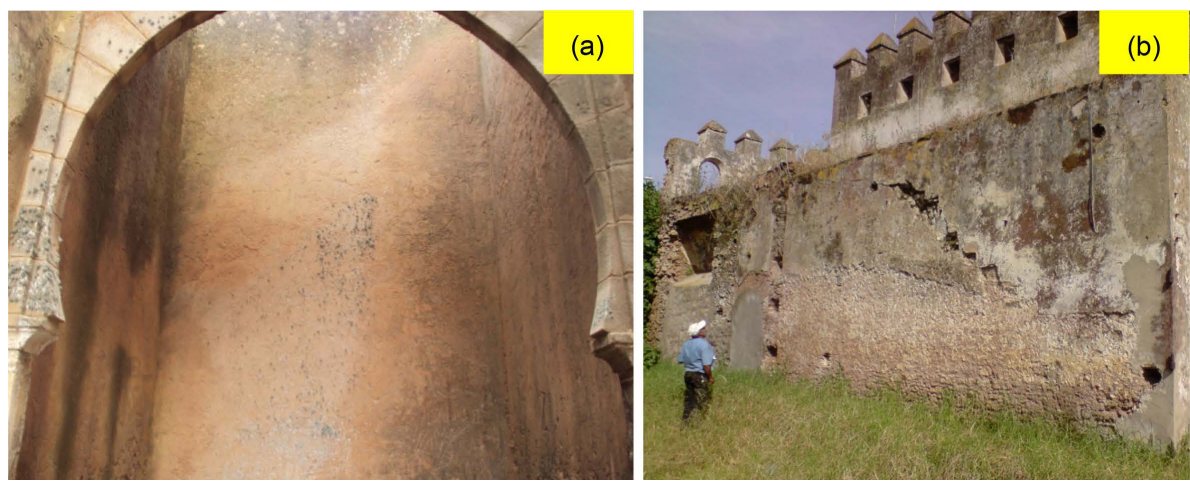

Figure 6. Development moss and lichen on a facade of a wall at the Kasbah of Mehdia (a) and the Kasbah of Kenitra (b).
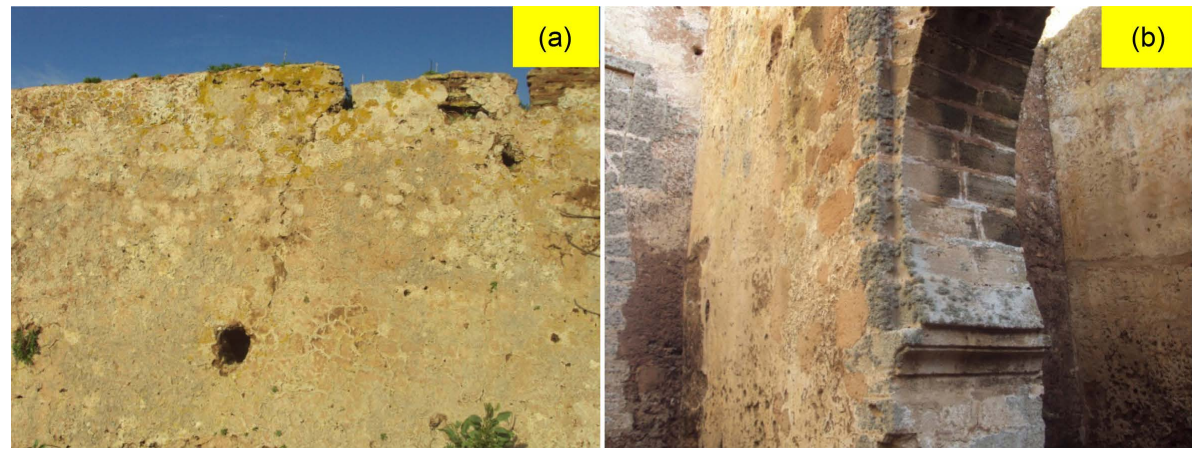

Figure 7. Development of lichen and algae (red and green) at the top of the wall (a) and lichens and algae at the base of another wall at the Kasbah of Mehdia (b). 
At both Kasbah of the Gharb region, the studied buildings also suffer the action of algae and lichens. Algae sometimes cover the facings locally and organisms related thereto; this finding is still linked to the presence of moisture. The existence of this vegetation is mainly visible in the basements of the facades or in the zones in contact with the ground, because of the upwelling of water by capillarity. The presence of algae on a facing is important to quickly locate moisture on an element.

This work coupled with an another study about the other important degradations of the construction materials used in the edification of the kasbahs studied in Kenitra and Mehdia, will serve, certainly, as an important document, for the specialists, to propose tangible solutions for a better preservation and a rehabilitation of these monuments.

\section{References}

[1] Benbdallah, A. (1975) Villes et Tribus du Maroc, Imprimerie Fédala.

[2] Dalimi, M. (2013) Contribution à l'étude de la dégradation des monuments historiques situés sur la façade atlantique du Maroc. Thèse de Doctorat, Univ. Hassan II Mohammedia -Casablanca, Faculté des Sciences et Techniques de Mohammedia.

[3] Taleb, A. (1995) Flore illustrée des adventices des cultures du Gharb. Thèse Doctorat èsSciences Agronomiques, Institut Agronomique et Vétérinaire Hassan II, Maroc, 2 volumes, $369 \mathrm{p}$.

[4] Fennane, M., Ibn Tattou, M., Mathez, J., Ouyahya, A. and El Oulaidi, J. (EDS) (1999) Flore pratique du Maroc. Vol. 1, Travaux Institut Scientifique, Rabat, Service. Botanique 36, Rabat.

[5] Fennane, M., Ibn Tattou, M., Ouyahya, A. and El Oulaidi, J. (EDS) (2007) Flore pratique du Maroc. Vol. 2, Travaux Institut Scientifique, Rabat, Service. Botanique 38, Rabat.

[6] Fennane, M., Ibn Tattou, M. and El Oulaidi, J. (EDS) (2014) Flore pratique du Maroc. Vol. 3, Travaux Institut Scientifique, Rabat, Service. Botanique 40, Rabat.

[7] Jahandiez, E. and Maire, R. Catalogue des plantes du Maroc 1931, 1932, 1934. Éditions Lechevalier, Paris, 3 Volumes, 913.

[8] Taleb, A. and Maillet, J. (1994) Mauvaises herbes des céréales de la Chaouia (Maroc). I. Aspect floristique. Weed Research, 34, 345-352. https://doi.org/10.1111/j.1365-3180.1994.tb02003.x

[9] Bourhim, B. (2009) Inventaire des altérations et de la biodégradation de la kasbah de Mehdia, mémoire de $3^{\text {ème }}$ cycle, Diplôme d'ingénieur d'état en agronomie, (IAV. Hassan II, Rabat).

[10] Raunkiaer, C. (1905) Types biologiques pour la géographie botanique. Bulletin Académique, Revue Scientifique Danemark, 347-437.

[11] Warscheid, T. and Braams, J. (2000) Biodeterioration of Stone: A Review. International Biodeterioration \& Biodegradation, 46, 343-368. https://doi.org/10.1016/S0964-8305(00)00109-8

[12] Baghdad, B., Taleb, A., Bouhache, M., El Mouhadi, M., Ballesteros, E.M. and Iñigo, A.C. (2005) Flore nuisible aux monuments historiques du Maroc: Cas des villes de Rabat et Sale.

[13] Phillipon, J., Jeannette, D. and Lefevre, R. (1990) Altération des pierres monumentales en France. CNRS édition/Ministère de la Culture, Paris.

[14] Seaward, M.R.D. (1997) Major Impacts Made by Lichens in Biodeterioration Processes. International Biodeterioration \& Biodegradation, 40, 269-273. 
https://doi.org/10.1016/S0964-8305(97)00056-5

[15] Bromblet, P. and Martinet, G. (2002) Joints, mortiers de pose et produits de ragréage (2 $2^{\text {ème }}$ partie) Les différentes pathologies. Réflexions et préconisations. Pierre Actual 785, janvier 2002, 66-77.

[16] Zaouia, N. (2007) Contribution à l'étude de l'altération de la Calcarénite en œuvre dans les monuments de Rabat. Influence de la pollution atmosphérique et des aérosols marins. Thèse de Doctorat, Univ. Mohammed V-Agdal, Faculté des Sciences, Rabat.

Submit or recommend next manuscript to SCIRP and we will provide best service for you:

Accepting pre-submission inquiries through Email, Facebook, LinkedIn, Twitter, etc. A wide selection of journals (inclusive of 9 subjects, more than 200 journals)

Providing 24-hour high-quality service

User-friendly online submission system

Fair and swift peer-review system

Efficient typesetting and proofreading procedure

Display of the result of downloads and visits, as well as the number of cited articles

Maximum dissemination of your research work

Submit your manuscript at: http://papersubmission.scirp.org/

Or contact oje@scirp.org 